This manuscript is contextually identical with the published article: Merényi, Zs., Varga, T., Geml, J., Orczán, Á. K., Chevalier, G., \& Bratek, Z. (2014). Phylogeny and phylogeography of the Tuber brumale aggr. Mycorrhiza. doi:10.1007/s00572-014-05667

The original publication is available at: http://link.springer.com/10.1007/s00572-014-05667

\title{
Phylogeny and phylogeography of the Tuber brumale aggr.
}

Zsolt Merényi; Torda Varga; József Geml; Ákos Kund Orczán; Gerard Chevalier; Zoltán Bratek

Z. Merényi; T. Varga; Á. K. Orczán; Z. Bratek (*)

Institute of Biology, Department of Plant Physiology and Molecular

Plant Biology, Eötvös Loránd University, Budapest, Hungary

e-mail: bratek.zoltan@ttk.elte.hu

G. Chevalier

UMR 1095 INRA-UBP, GDEC, 5 chemin de Beaulieu, 63039 Clermont-Ferrand Cedex 2, France

J. Geml

Naturalis Biodiversity Center, P.O. Box 9517,

2300 Leiden, RA, The Netherlands

\section{Abstract}

The Tuber brumale (winter truffle) is a black truffle reported from most European countries, belonging to the Melanosporum group. Its significance in the economy is ambivalent as the winter truffle has been shown to be a frequent contaminant species in the orchards of the Perigord truffle and occasionally in those of the summer truffle, yet owing to its delicate fragrance, its trade is worthy of note. The phylogeny and phylogeography of economically important truffles are relatively well-explored; however, no thorough research has been published on these aspects of the winter truffle. Therefore, here, we report the first phylogeographic analyses based on samples representing the entire distribution of the species. ITS sequences were used in this survey for haplotype and coalescent analyses, while phylogenetic analyses were based on the ITS, LSU and PKC loci. According to all loci, the samples clustered into two big clades imply the existence of two phylogenetic species. Based on our results, one of these appears to be endemic to the Carpathian Basin. In the other more widespread species, two main phylogeographic groups can be distinguished that show east-west separation with a zone of overlap in the Carpathian Basin, suggesting that they survived the latest glacial period in separate refugia.

\section{Introduction}


The genus Tuber, containing hypogeous species indigenous in the Northern hemisphere, comprises the largest group in the ascomycete family Tuberaceae in the order Pezizales (Bonito et al. 2010, 2013). Numerous gastronomically and economically remarkable fungi belong here including the winter truffle (Tuber brumale Vittad.) which is one of the most significant members of the genus. Its reputation is demonstrated by the fact that in French marketplaces, the name 'truffle' is reserved exclusively for Tuber melanosporum Vittad. (Perigord truffle) and Tuber brumale (Douet et al. 2004). The organoleptic features of the winter truffle are also similar to that of T. melanosporum resulting in a prominent gastronomical status (Kiss et al. 2011). Phylogenetically, the winter truffle is closely related to the Perigord truffle (Bonito et al. 2013), the genome of which has been fully sequenced (Martin et al. 2010). T. brumale forms ectomycorrhizae and, like most species in the genus, is not strictly host-specific (Chevalier and Frochot 1997; Hall et al. 2007). It is one of those representatives of Tuber that can become non-native colonizers in regions distant from their original habitats (Bonito et al. 2010) and frequently appear in cultivated truffle orchards (Chevalier and Frochot 1997; Benucci et al. 2011; Belfiori et al. 2012; Olivier and Savignac 2012; Guerin-Laguette et al. 2013). Several articles have issued the effects of $\mathrm{T}$. brumale on other truffles; negative, suppressing effects are underlined mainly by handbooks (Chevalier and Frochot 1997; Sourzat 2011; Chevalier and Sourzat 2012; Olivier et al 2012). Mamoun and Olivier (1993) have revealed that negative impacts are greatly dependent on environmental factors such as irrigation strategies. The competitive properties of the economically important truffle species against other ectomycorrhizal fungi vary, as can be concluded from the compositional and quantitative differences of mycorrhizal communities in truffleorchards (Belfiori et al. 2012).Eleven major clades are currently recognised withinthe genus Tuber (Bonito et al. 2013), including theMelanosporum major clade which further branches intotwo lineages (Jeandroz et al. 2008). The first one contains theT. melanosporum, Tuber regiomontanum Guevara, Bonito,and Rodríguez (Guevara et al. 2008; Bonito et al. 2013) andTuber indicum Cooke and Massee species complex whilst thesecond lineage comprises Tuber pseudoexcavatumWang et al.and T. brumale. The same origin of the latter two species isconfirmed by, inter alia, a 300-bp long insertion in the internaltranscribed spacer 1 (ITS1) region (Wang et al. 2006).According to Wang et al. (2006), the most recent commonancestor (MRCA) of the Melanosporum cladeprobably existed between China and Europe. First, theT. pseudoexcavatum/T. brumale lineage diverged and the ancestorof T. brumale commenced its migration towards Europewhile that of T. pseudoexcavatum moved towards China. Theancestors of T. melanosporum and T. indicum diverged later,but followed similar migration routes to Europe and China,respectively, thus also forming a vicariant species pair. On theother hand, according to Bonito et al. (2013), the radiation ofthe Melanosporum clade began in North America 79 millionyears ago (Ma) connected to host plants of the familyPinaceae, followed by migration towards Asia and toEurope. Furthermore, the low nucleotide variability foundsolely in 
European species suggests a strong bottleneck effectin their history (Murat et al. 2004; Wang et al. 2006).T. brumale is widespread in almost all of Europe except inboreal and arctic regions (Hollós 1911; Ławrynowicz 1992;Montecchi and Sarasini 2000). In 1995, it was also found inNew Zealand on account of human-mediated propagation(Ho et al. 2008). It is thought to be rare or absent in somecountries (England, Germany, Poland and Scandinavia;Benjamin Stielow, Christina Wedén, Maria Ławrynowicz,Marie-Anne French pers. comm.) and common in others(France, Hungary, Italy, Romania, Serbia and Slovenia;Grebenc 2008; Marjanović 2008; Bratek et al. 2013; andAlessandra Zambonelli and Gérard Chevalier pers. comm.).It should be noted that winter truffles are dog preferred hypogeousfungi (DPH; Bratek et al. 2013), and their collection fortrade may severely influence estimations of their abundance.Beheregaray (2008) showed that 3,049 articles dealingwith phylogeography were published between 1987 and2006 with as few as 13 concerned with fungi (e.g., Hibbett2001; Geml et al. 2006), which highlights the need of fungalphylogeographical research. Lumbsch et al. (2008) alsomentionthe scarce use of phylogeographical methods in mycology,although several surveys were released on the subjectafterwards (e.g., Linzer et al. 2008; Moncalvo and Buchanan2008; Bergemann et al. 2009; Ghikas et al. 2010; Grubishaet al. 2012). Still, fungi are vastly understudied with respect tophylogeography and taxonomic diversity. On the basis of all these, it is not surprising that the winter truffle is one of the most intensely studied Tuber species. The assessment of its distribution and genetic variability could reveal important findings for the ecological, conservation and biological and economical research of this mushroom. The aim of this work is to characterize the phylogeographic structure of the T. brumale species complex covering its entire known distribution. In our molecular study, 194 specimens from 19 countries were analyzed to test for correlations between spatial and genetic patterns, including the estimation of gene flow among geographic areas and the detection of evolutionary lineages undergoing speciation.

\section{Materials and methods}

\section{Sampling}

Our sample includes 194 localised findings of T. brumale andT. brumale var. moschatum (Bull.) Hall et al. (OnlineResources 1, 2). Most of these originate from the knownnative distributional area of this species (Europe), with theexception of three findings (two from Iran and one from NewZealand). Our goal was to perform an even and representativesampling, with a large enough sample size, covering thebiogeographical area of the winter truffle as entirely aspossible. Fresh or dried ascomata from different countrieswere determined and kindly provided by collectorsfrom the CarpathianPannonian region and also by AlessandraZambonelli, Amer Montecchi, Chriss 
Chrysopoulos,Diamandis Stephanos, Gérard Chevalier, Joseph Maria Vidaland Stanislav Glejdura. These, 136 specimens in all, weredeposited in Zoltán Bratek’ s herbarium (ZB).

\section{Isolation of DNA, PCR and sequencing}

DNA was isolated from dried or fresh sporocarps withDNeasy Plant Mini Kit (Qiagen) or DNA Mini Kit (Plant)(Geneaid) according to the instructions of the manufacturerswith minor modifications. Three nuclear loci were analysedfor phylogeny; these are the ribosomal internal transcribedspacer (ITS), the large subunit (LSU) regions of the ribosomalDNA repeat and the variable segment of the protein kinase $C(P K C)$ locus. The LSU is closely linked to the ITS, while thePKC is not linked to the previous two. Primers used for theamplification of the ITS region were normally ITS1F, ITS4(White et al. 1990; Gardes and Bruns 1993), and in case ofproblematic samples, ITS5, ITS6 and ITS7 (Bertini et al.1999). For the LSU region LROR, LR3 (Vilgalys and Hester1990), for the PKC region PKC1F, PKC1R (Ambra andMacino 2000) primers were used. PCRs were performed witha final volume of $50 \mu \mathrm{l}$ : the components are as follows:DreamTaq Green Buffer (Fermentas) $(20 \mathrm{mM} \mathrm{MgCl2,5.0 \mu l),} \mathrm{dNTPmix}$ (Fermentas) $(2 \mathrm{mM}, 5.0 \mu \mathrm{l})$, primers forlTS $(0.01 \mathrm{mM}, 1.0 \mu \mathrm{l})$ or LSU $(0.01 \mathrm{mM}, 1.0 \mu \mathrm{l})$ or PKC $(0.05$ $\mathrm{mM}, 1.0 \mu \mathrm{l})$, Milli-Q water $(12.75 \mu \mathrm{l})$, DreamTaqpolymerase (Fermentas) $(5$ unit/ $\mu \mathrm{l}, 0.25 \mu \mathrm{l})$ and templateDNA dissolved in Milli-Q water $(25.0 \mu \mathrm{l})$. Thermocyclingwas carried out under the following conditions: $94{ }^{\circ} \mathrm{C}$ for $10 \mathrm{~min}, 33$ cycles of $94^{\circ} \mathrm{C}$ for $30 \mathrm{~s}, 51{ }^{\circ} \mathrm{C}$ (ITS) or $54{ }^{\circ} \mathrm{C}(\mathrm{LSU})$ or $58^{\circ} \mathrm{C}$ (PKC) for 30 (alternatively 60 )s and $72^{\circ} \mathrm{C}$ (elongation) for $45-120 \mathrm{~s}$ (depending on thetypes of primers). ABI Prism BigDye $^{\mathrm{TM}}$ Terminator CycleSequencing Ready Reaction Kit 3.1 (Applied Biosystems)was applied for sequencing. Capillary gel electrophoresiswas accomplished by ABI PRISM 3100 Genetic Analyzer(Applied Biosystems) according to the instructions of themanufacturer (Biomi Ltd.).Restriction fragment length polymorphism (RFLP)was used for the quick, simple and cheap detection oflineages identified earlier. Hinfl and Mbol restriction endonucleaseswere applied on the basis of preliminary in silicodigestions (SnapGene ${ }^{\circledR}$ software, GSL Biotech; available atsnapgene.com) of sequenced ITS loci. ITS products of $2 \mu$ lwere digested overnight at $37{ }^{\circ} \mathrm{C}$ with 1.25 units of one of theendonucleases per reaction. Restriction fragments wereseparated in $3 \%$ agarose gels. On the whole, 108 sampleswere sequenced for at least one locus, 28 samples wereidentified with RFLP and 58 samples were collected throughNCBI (http://www.ncbi.nlm.nih.gov/). Thus, our phylogeneticanalyses included 136 ITS region, 31 LSU region, and 24 PKCsequences.

\section{Phylogenetic and haplotype analyses}

Electropherograms were checked with the program FinchTV1.4.0 (Geospiza, Inc., Seattle, WA, USA; http://www.geospiza.com). Alignment of sequences was carried out withthe softwareMAFFT (Katoh 
and Toh 2008).Alignments weremanually corrected with MEGA 5 (Tamura et al. 2011)when needed. File formats were transformed with the onlineapplication ALTER (Glez-Pena et al. 2010).Phylogenetic analyses were executed with PAUP(Swofford 2003) and MrBayes 3.1.2. (Huelsenbeck andRonquist 2001) program packages. Filograms generated withmaximum parsimony (MP) were calculated in two ways, thatis, with 'missing' and 'new state' gap handling. Tree-bisection-reconnection (TBR) branch-swapping option was chosenfor heuristic searches with 100 bootstrap replicates for eachlocus. The suitable substitution matrices for Bayesian analyseswere selected with MrMODELTEST v2.3 (Nylander 2004).With regard to Akaike Information Criterion (AIC), the bestfitlikelihood models were found to be the HKY+G, GTR+Gand GTR for ITS, LSU and PKC, respectively. Phylogeneticreconstructions performed by MrBayes ran in four chains with12,000,000 generations for ITS and 10,000,000 generationsfor LSU and PKC. Every 100th generations were sampled.Average standard deviations of split frequencies were0.007224 for ITS, 0.003314 for LSU and 0.001210 forPKC. Phylogenetic trees were visualized by FigTree v1.3.1(Rambaut 2009). To test for congruences of gene genealogies, partition homogeneity test (PHT) was used within the programPAUP (Farris et al. 1995; Swofford 2003). Paired nucleotidedivergence values were also calculated with PAUPselecting the P-distance option. Haplotype diversity was determined with the DNAsp software(Librado and Rozas 2009). Haplotypes were recognisedby the program Collapse (Posada 2011). The haplotype networkswere made using the TCS program (Clement et al.2000) and visualized with Cytoscape (Shannon et al. 2003).The distribution of the main lineages, based on the 194samples, was visualized by Quantum GIS mapping software(http://qgis.org). To better understand the causes of haplotypepatterns, DNAsp was used to calculate Tajima' s D (Tajima1989), Fu' s Fs (Fu 1997), Fu and Li' s D* and Fu and Li's $\mathrm{F}^{*}(\mathrm{Fu}$ and Li 1993) neutrality tests (based on 1,000 coalescentsimulations).

\section{Molecular dating}

Divergence times of Melanosporum clade members wereestimated with BEAST version 1.8 (Drummond et al. 2012).We employed a secondary calibration approach based onBonito et al. (2013) to compensate the absence of fossilrecords in the Melanosporum group. For the molecular clockanalysis, the ITS1 region was neglected because ITS1 is toodivergent; thus, the 5.8S, ITS2 and LSU dataset was analyzed.The clock model and substitution models were unlinked.jModeltest (Posada 2008) was used to select the substitutionmodels for each locus (5.8S: HKY; ITS2: N93+G;LSU:GTR+I). We created two monophyletic taxon sets, onecontaining the species of the Melanosporum clade and theother containing only T. brumale and T. pseudoexcavatumsequences. Analyses were run under an uncorrelated lognormalrelaxed molecular clock, setting the tree prior to 
the birth-death speciation process. We used normal prior distributionsfor the node with value of Melanosporum clade (mean=79.7 Ma, SD=5 Ma). Priors were set to the default exceptthe clock rates (substitution per site per million years) ofunlinked regions which were set as follows: $5.8 \mathrm{~S}=3.02-4, \mathrm{ITS} 2=2.07-3$ and $\mathrm{LSU}=6.5-4$ (Bonito et al. 2013). TheMCMC analysis was run for $50,000,000$ generations, andevery 5,000th tree was sampled. To check if the effectivesample sizes reached the appropriate value, we usedTRACER version 1.5 (Rambaut and Drummond 2009). Wecalculated the maximum clade credibility tree using TreeAnnotator version 1.8 (available as part of the BEASTpackage) after the initial $10 \%$ of the trees were discarded.

\section{Coalescent analyses of $\mathrm{T}$. brumale populations}

Identical ITS sequences were collapsed into haplotypes usingSNAP Map (Aylor et al. 2006) after excluding insertion ordeletions (indels) and infinite-sites violations. The analysespresented here assume an infinite sites model under which apolymorphic site is caused by exactly one mutation and therecan be no more than two segregating bases. Base substitutionswere categorized as phylogenetically uninformative or informativeand as transitions or transversions. Site compatibilitymatrices were generated from each haplotype dataset usingSNAP Clade and Matrix (Markwordt et al. 2003; Bowdenet al. 2008) to examine compatibility/incompatibility amongall variable sites, with any resultant incompatible sites removedfrom the dataset. Genetic differentiation among geographicalpopulations was analysed using SNAP Map,Seqtomatrix and Permtest (Hudson et al. 1992) implementedin SNAPWorkbench (Price and Carbone 2005). Permtest is anonparametric permutation method based on Monte Carlosimulations that estimates Hudson' s test statistics (KST, KSand KT) under the null hypothesis of no genetic differentiation.KST is equal to $1-\mathrm{KS} / \mathrm{KT}$, where $\mathrm{KS}$ is a weighted mean of K1and K2 (mean number of differences between sequences inhaplogroups I and

II, respectively), and KT represents themean number of differences between two sequences regardlessof the subpopulation to which they belong. The nullhypothesis of no genetic differentiation was rejected atp $<0.05$. For this test, $T$. brumale specimens were assigned togeographical groups (Western vs. Eastern Europe) thatcorresponded to haplogroups I and II, respectively.We usedMDIV (Nielsen andWakeley 2001), implementedin SNAP Workbench (Price and Carbone 2005), employingboth likelihood and Bayesian methods using Markov chainMonte Carlo (MCMC) coalescent simulations to estimate themigration (M), population mean mutation rate (Theta) anddivergence time $(T)$. Here, $M$ equals $2^{\prime}$ the net effectivepopulation size ( $\mathrm{Ne}$ ) multiplied by $\mathrm{m}$ (migration rate), whileTheta is $4^{\prime}$ Ne multiplied by $\mathrm{m}$ (mutation rate) (Watterson1975). Ages were measured in coalescent units of $2 \mathrm{~N}$, whereN is the population size. This approach assumes that allpopulations descended from one panmictic population thatmay or may not have been followed by 
migration. For eachdataset, the data were simulated assuming an infinite sitesmodel with uniform prior. We used 2,000,000 steps in thechain for estimating the posterior probability distribution andan initial 500,000 steps to ensure that enough genealogieswere simulated before approximating the posterior distribution.Subsequently, we reconstructed the genealogy with thehighest root probability, the ages of mutations and the time tothe most recent common ancestor (TMRCA) of the sampleusing coalescent simulations in Genetree v. 9.0 (Griffiths andTavaré 1994).

\section{Results}

\section{Phylogenetic analyses}

A total of 108 samples were successfully sequenced, another58 sequences of T. brumale and 69 sequences of closelyrelated species were downloaded from databases of NCBI(Online Resource 1). We gathered 140 ITS, 92 LSU and 28PKC sequences for subsequent phylogenetic analyses. Thus, the sample size was sufficient to study the phylogeny ofT. brumale and accomplish our abovementioned objectives. The constructed parsimony trees, based on ITS, LSU andPKC regions, are shown in Table 1. Phylogenetic trees ofthe same locus revealed identical topologies regardless ofmethod (Bayesian or Parsimony) and types of gap handlingwith only one exception: the tree based on ITS with gapsscored as a new state. This deviation was a result of anapproximately $300 \mathrm{bp}$ long insertion located in the ITS ofT. brumale mentioned in the "Introduction". On the LSU tree(Fig. 1), the samples represent a separate monophyletic clustercontaining two clades (clades A and B) of high support withinthe Melanosporum group. Two further groups can be distinguished(I and II) within clade A; however, only group II canbe considered as monophyletic. The ITS and PKC trees(Fig. 2, Online Resource 4) confirm the highly supportedclades (A and B). However, unlike the LSU and ITS trees, clade A does not separate into two groups on the PKC tree.Therefore, calculating a concatenated tree was unadvisable, which was also affirmed by the significant result of the PHTtest $(p=0.0004)$. Nucleotide distance between groups I and II of clade A, ascalculated by the P-distance method, suggests an intraspecificvariability (2.02 \%) below the generally applied limit of $3 \%$ (Nilsson et al. 2008; Bonito et al. 2010), while the distancebetween clades A and B (9.32 \%) is large enough to beregarded interspecific (Table 2).Clades A and B as well as haplotype groups I and II inclade A could be clearly identified based on RFLP fragmentpatterns acquired with the use of $\mathrm{Mbol}$ and Hinfl restrictionenzymes; both of these enzymes have three to five restrictionsites in the ITS segment. As DNA fragments shorter than100 bp cannot be sufficiently separated using $3 \%$ agarosegel, only fragments of 100 to $550 \mathrm{bp}$ were informative. Withregard to the enzyme $\mathrm{Mbol}$, these are the 121, 303 and 368 bpfragments for clade B; fragments of 227, 231 and 306 bp forhaplogroup I in clade A; and fragments of 142, 225, 231 and307 bp for haplogroup II in clade A.With regard to Hinfl, 223and 
$528 \mathrm{bp}$ for clade B; 140, 226 and $402 \mathrm{bp}$ for haplogroup lin clade A; and 227 and $540 \mathrm{bp}$ for haplogroup II in clade A.Clades A and B could be distinguished using $\mathrm{Mbol}$ as the 368-bp long fragment was only present in clade B. Detection of thetwo haplogroups in clade A was made possible by fragmentssized 140 and 402 bp digested by Hinfl, both unique forhaplogroup I.

\section{Phylogeography and haplotype analysis}

One hundred thirty-six sequences were involved in ITS haplotypeanalyses: 119 sequences for clade A and 17 for clade B,both examined separately (Fig. 3). Altogether, 17 haplotypeswere found in clade A and two haplotypes in clade B. Aswas seen on the ITS and LSU trees, two distanthaplogroups can be observed on the haplotype networkof clade $A$, which are 16 mutation steps far from eachother. The most abundant haplotype in haplogroup I is $\mathrm{C} 1$ with a frequency of $84.1 \%$ from which the rest ofthe haplotypes branch in a star-like shape with distances of1-2 mutations. Haplotype diversity (Hd) of haplogroup I is 0.29 . In contrast, $\mathrm{Hd}$ of haplogroup II is 0.72 , and the mostcommon haplotype belonging here (K1) has a frequency of $43.2 \%$; thus, haplotypes are more evenly distributed. Samplesof clade B cluster in two haplotypes of similar size, resultingin a $\mathrm{Hd}$ value of 0.53.Phylogeographic analyses were performed based on 194samples including sequences needed for phylogeny as well aspartial sequences and samples identified with RFLP. Clade Awas found to be distributed across Europe, whilst clade Bturned out to be restricted to the Carpathian-Pannonian region(Fig. 3, OnlineResource 2). This means that the distribution ofthe two clades is sympatric. Representatives of haplogroup I(clade A) were detected from Western Europe to the easternand southern parts of Hungary. On the other hand, specimensof haplogroup II were shown from locations that lie to the eastof the Alps. Therefore, the distribution of the two haplogroupswithin clade $A$ is to be considered parapatric with a contactzone in the Carpathian Basin.Several interesting haplotypes were identified within cladeA such as a sample from New Zealand (EU753268) shownfrom roots. This belongs to the most frequent haplotype (C1)and was presumably transported overseas from France withinoculated seedlings. Likewise, all specimens from theCarpathian Basin belong to haplotype $\mathrm{C} 1$. Haplotype C2,found only in Italy, is a curiosity having an ITS1 region witha 33-bp long deletion. The two sequences identified fromlranian root samples are unique that only constitute haplotypeL.Tajima' s D, Fu' s Fs, Fu and Li' $s D^{*}$ and Fu and Li' $s F^{*}$ were non-significant for haplogroup II, clade A and clade B(with $95 \%$ confidence intervals). For haplogroup I, all ofthe tests were significant $\left(D=-0.07, p=0.003 ; F^{*}=-0.17, p=0.03 ; F s=-0.17, p=0.02\right)$ except the Fu and Li' $s D^{*}$.

\section{Molecular dating}


The estimates of divergence times and the chronogram areshown in Online Resource 5 . The result of the posteriorMRCAwas $78.0 \mathrm{Ma}$, and the posterior clock rates of unlinkedregions were $5.8 \mathrm{~S}=1.97-4$, ITS2 $=4.56-3$ and LSU=8.51-4. These values are similar to the results of Bonito et al. (2013). The split of the T. brumale clade A from clade B likely occurred17.9 Ma (95 \% high posterior density, 10.9-25.7 $\mathrm{Ma})$.

\section{Coalescent analyses of $\mathrm{T}$. brumale populations}

Estimates of Hudson's test statistics (KST, KS and KT) usingnonparametric permutation method indicated strong geneticdifferentiation among haplogroups I and II. The genetic differenceswithin and between populations were $\mathrm{KS}=5.9036$ and $\mathrm{KT}=7.1813$, respectively, resulting in $\mathrm{KST}=0.1780, p<0.0001$. In our combined approach, MDIV was used to estimategene flow and to determine if the diversity patterns in theWestern and Eastern populations of clade Awere the result ofretention of ancestral polymorphism or recent gene flow. Afterrecoding indels and removing infinite-sites violations from theoriginal ITS datasets, there were 13 ITS haplotypes in populationsof T. brumale, respectively (Table 3). MDIV showedevidence for no gene flow $(M=0)$ and statistically significant,non-zero population divergence time $(0<T)$ (Online Resource6). Coalescent genealogies generated by Genetree simulationsconfirmed the historical population division betweenhaplogroups I and II. Even though the initial settings werebased on the conservative null hypothesis of a panmicticpopulation with a moderately high level of migration( $M=0.1)$ between geographic populations, the separationof the two haplogroups was evident on the genealogy withinferred mutational history and variation between and withingeographical regions (Fig. 4).

\section{Discussion}

Phylogenetic and phylogeographic analyses of T. brumale were carried out in this study using 194 samples identified as T. brumale or T. brumale var. moschatum attempting to cover the entire biogeographic area of this species. Two of the three utilized phylogenetic markers (ITS and LSU) are closely linked, yet because of their functional differences, their mutation rates differ greatly. PKC is not linked with the aforementioned sites and its evolution is slow (Wang et al. 2006). The separation of clades A and B was highly supported by all examined loci, and they are recognised as distinct phylogenetic species based on gene genealogical concordance sensu Taylor et al. (2000). The distinction of haplogroups I and II within clade A is supported by both ITS and LSU while it is unsupported by PKC. This incongruence is further demonstrated by the significant outcome of the PHT test. The congruent distinction of clades A and B and the incongruent distinction of haplogroups I and II stand on opposite sides of the 'species boundary' , i.e. the former two are different species 
while the latter two are the same. The lack of segregation of haplogroups I and II observed on the PKC tree could be a consequence of either current recombination or recent separation with the ancestral polymorphic alleles still present. Coalescence analyses favour recent separation, according to which gene flow between the two haplogroups ceased some time ago. Recent separation is also supported by the notable distance in ITS (2.02\%) and the divergence time not being zero. The picture is much clearer concerning the segregation of clades A and B. The genetical distance of ITS between them (9.3\%) exceeds $3 \%$ indicating that they are to be considered separate phylogenetic species (Nilsson et al. 2008; Bonito et al. 2010), which is corroborated by the gene genealogical concordance of the three loci. The sympatric distribution of the two clades and their reciprocal monophyly indicates a lack of genetic exchange between them (Bickford et al. 2007). Furthermore, the results of molecular dating indicate that the split of clades A and B was $17.9 \mathrm{Ma}$ (Online Resource 5) which is similar to the divergence time of T. melanosporum and T. indicum species complex (Bonito et al. 2013). According to these results, clades A and B can be considered as two different phylogenetic species. Some previous studies showed morphological differences between T. brumale and T. brumale var. moschatum (for examples, see Riousset et al. 2001), but neither our molecular results nor Gandeboeuf et al. $(1994,1997)$ support this differences. Nota bene, both T. brumale and T. brumale var. moschatum were described in Western Europe, a geographic region where T. brumale s.l. is genetically homogeneous (haplogroup I) according to our results. Thus, it is unlikely that these putative morphological differences are an outcome of speciation. Other studies (e.g. Montecchi and Sarasini 2000; Ceruti et al. 2003) failed to show any morphological differences between ascomas of clades $A$ and $B$, though they gathered specimens from locations where the geographic areas of these two clades overlap. Therefore, they might be assumed as members of a cryptic species complex, i.e. distinct phylogenetic lineages previously lumped under the same name due to the lack of observed morphological differences (Bickford et al. 2007). Several other Tuber taxa, including Tuber borchii Vittad. (Bonuso et al. 2009) and T. indicum (Chen et al. 2011), have also turned out to contain cryptic species. T. indicum is a close relative of T. brumale aggr. In the case of T. brumale aggr., it is possible that examining character combinations will solve the morphological differentiation of the two clades. A more thorough morphological investigation shall be the subject of future research. The formal taxonomic treatment of these taxa is also a promising direction, but until there is no novel morphological species description, T. brumale should be treated as a species aggregate. For this reason and because of the phylogenetic species differentiation of clades $A$ and $B$, it is more appropriate to use T. brumale aggr. instead of T. brumale Vittad. Previous studies underline the low genetic variability of T. brumale s.l. Using isoenzyme methods and random amplified polymorphic DNA (RAPD), Gandeboeuf et al. $(1994,1997)$ suggested that the intraspecific variability of T. brumale s.l. was lower than that of other members of Tuber. Giomaro et al. (2002) found no variability in the 
ITS region of the species in question, which was confirmed later by Pomarico et al. (2006). Wang et al. (2006) showed that among the main representatives of the Melanosporum group, nucleotide divergence was lower in European species (T. melanosporum, 0.0-0.3 \%, T. brumale s.l., 0.0-0.1 \%) than in Asian species (T. indicum, $3.2 \%$; T. pseudoexcavatum, $1.0 \%$ ). These authors attributed this to a bottleneck effect occurring in the course of migration toward Europe. A further bottleneck effect is assumed to have taken place during the previous glacial period in the case of European T. melanosporum populations (Bertault et al. 2001; Murat et al. 2004). Bonito et al. (2010) showed less then $0.5 \%$ intraspecific variation in T. brumale. Here, we present a higher ITS variability in T. brumale s.I. than was previously believed. Our data shows that intraspecific ITS variabilities of clades A and B are 0.91 and $0.07 \%$, respectively, meaning that clade B does harbour low variability while that of clade A is relatively high. Intraspecific ITS variabilities of haplogroups I and II are 0.032 and $0.201 \%$, pointing out that intergroup differences contribute the most to the genetic variation found in clade A. In the Tuber genus, three other species show ITS variability similar to that of clade B (less then 0.2 $\%$; Tuber puberulum, Tuber castellanoi and Tuber oregonense) and one species similar to that of clade A (<1 \%; Tuber mesentericum) (Bonito et al. 2010). Low nucleotide and haplotype variability and the starshaped structure of the haplotype network of haplogroup I suggest recent expansion (Slatkin and Hudson 1991). The significant negative results of Tajima's D, Fu's Fs and Fu and Li's $F^{*}$ tests support the recent expansion of this haplogroup. Based on the present distribution of haplogroup I, it is likely that its populations survived the last glacial in Western European refugia. Looking at the phylogeographical investigations of potential host plant of T. brumale aggr., similarities appear in the haplotype patterns of the winter truffle and its hosts. For instance, dominance of one haplotype was observed in the case of white oak species (Quercus spp.) and the common hazel (Corylus avellana) in France. These host trees survived the last glacial in Iberian refugia (Palmé and Vendramin 2002; Petit et al. 2002a, b). In contrast to this, beech (Fagus spp.) and hornbeam (Carpinus spp.) species are thought to have recolonised Europe mainly from the Italian Peninsula and the Balkan region, although these species had refugia in the Iberian Peninsula as well (Taberlet et al. 1998; Grivet and Petit 2003; Magri 2008). The recolonization of haplogroup I from two refugia (Iberian and Italian Peninsulas) is in conflict with the star-shaped structure of its haplotype network and the low genetic diversity of this group because should the two lineages of different refugia intermingle, the resulting diversity would be higher (Petit et al. 2003). Haplogroup II is more diverse, its nucleotide and haplotype variability is higher and the structure of its haplotype network is more complex. This greater diversity could be a result of surviving the last glacial in Eastern European refugia; the Balkan Peninsula harboured several refugia and recolonization routes as it has been identified in the case of other species (Petit et al. 2003; Magri 2008; Hatziskakis et al. 
2009). Despite the large number of samples, the other phylogenetic species (clade B) was only found within the Carpathian Basin. A notable number (20) of T. brumale aggr. samples collected to the east and south-east of the Carpathian Basin were at out disposal, but they all belonged to clade A. This suggests that clade B is indeed distributed solely in the Carpathian Basin and represents a fungus endemic to this region. The low nucleotide and haplotype diversity of clade B can indicate a strong bottleneck effect; however, the non-significant results of Tajima's D,Fu' s Fs, Fu and Li' s D* and Fu and Li' $\mathrm{s} \mathrm{F}^{*}$ tests do not support this assumption. Nevertheless, clade B could have survived the last glacial in a Carpathian refugium, a scenario also proposed concerning some tree species (Bordács et al. 2002; Petit et al. 2003; Magri 2008). It can be concluded, therefore, that the Carpathian Basin and the Balkan region are diversity hotspots not only for plant and animal species but also for certain macrofungi as well, e.g. the genus Tuber (Sica et al. 2007; Marjanović et al. 2010). These regions may be home to more undescribed endemic Tuber species. Digestion of the ITS region of T. brumale s.I. with Hinfl was utilized earlier by Giomaro et al. (2002) in order to quickly identify samples of this species. However, this enzyme is only capable of separating haplogroups I and II in clade A, while Mbol, used in our research, made it possible to distinguish clade A from clade B. The RFLP method allows for the time- and cost-efficient screening of T. brumale aggr. samples, which could contribute to surveys on populations of T. brumale aggr. in un- or undersampled regions such as the Middle East, Ukraine, Russia and Spain. In the present study, we identified an endemic phylogenetic sister species of T. brumale aggr. (clade B) and detected two remarkably different haplotype groups within clade A of T. brumale aggr. This finding provides new proof for the existence of hardly recognizable (cf. crypric/pseudocryptic) macrofungi species for which there are several other examples (e.g. Geml et al. 2006; Bonuso et al. 2009; Li et al. 2010; Van de Putte et al. 2010; Chen et al. 2011; Stielow et al. 2011; Sheedy et al. 2013; Urban et al. 2013). Furthermore, the assessment and protection of biodiversity require knowledge about species that are complicated to distinguish merely on morphological grounds. In addition, the discovery of endemic species, as the new Tuber sp. was shown here to be endemic to the Carpathian Basin, plays an important role in settling the proper conservation status of a specific area. Also, our work exemplifies the importance of sufficiently large sample size and broad geographical spread in sampling to achieve reliable approximations of the genetic diversity of a certain species. Our results may contribute to further physiological and ecological investigations of T. brumale aggr., leading to a deeper understanding of the biology and cultivation of truffles.

\section{Acknowledgments}


We are grateful to the people who provided us with specimens and coordinates, namely Alessandra Zambonelli, Amer Montecchi, Chriss Chrysopoulos, Diamandis Stephanos, Joseph Maria Vidal, Stanislav Glejdura and each truffle hunter in the First Hungarian Truffling Association. Especially, we thankMarjanović Zaklina and Tine Grebenc for the sequences and their data. We would like to thank Eszter Ari, Gábor Sramkó, Gergő Kutszegi and Sándor Bordács for their useful advice in phylogenetics and phylogeographics. We are also thankful to Tímea Bezeczki and Gabriella Tamaskó for their technical assistance. For servers and bioinformatics help, we express our gratitude to Dávid Fazekas and the website of Bioportal (https://www.bioportal.uio.no/). We are obliged to Erik Zajta and András Hubai for helping with the English language. This research was supported by the MIKOQUAL project under the Ányos Jedlik Programme and by the QUTAOMEL project under the National Technology Programme.

\section{References}

Ambra R, Macino G (2000) Cloning and characterization of PKChomologous genes in the truffle species Tuber borchii and Tuber magnatum. FEMS Microbiol Lett 189:45-53

Aylor DL, PriceEW, Carbone I (2006) SNAP: combine andmapmodules for multilocus population genetic analysis. Bioinformatics 22: 1399-1401

Beheregaray LB (2008) Twenty years of phylogeography: the state of the field and the challenges for the Southern Hemisphere. Mol Ecol 17: 3754-3774. doi:10.1111/j.1365-294X.2008.03857.x

Belfiori B, Riccioni C, Tempesta S, Pasqualetti M, Paolocci F, Rubini A (2012) Comparison of ectomycorrhizal communities in natural and cultivated Tuber melanosporum truffle grounds. FEMS Microbiol Ecol 81:547-561. doi:10.1111/j.1574-6941.2012.01379.x

Benucci GMN, Raggi L, Albertini E, Grebenc T, Bencivenga M,Falcinelli M, Di Massimo G (2011) Ectomycorrhizal communities in a productive Tuber aestivum Vittad. orchard: composition, host influence and species replacement. FEMS Microbiol Ecol 76:170- 184. doi:10.1111/j.1574$6941.2010 .01039 . x$

Bergemann SE, Smith MA, Parrent JL, Gilbert GS, Garbelotto M (2009) Genetic population structure and distribution of a fungal polypore, Datronia caperata (Polyporaceae), in mangrove forests of Central America. J Biogeogr 36:266-279. doi:10.1111/j.1365-2699.2008. 02006.x 
Bertault G, Rousset F, FernandezD, Berthomieu A,HochbergME, Callot G, Raymond M (2001) Population genetics and dynamics of the black truffle in a man-made truffle field. Heredity $86: 451-458$

Bertini L, Amicucci A, Agostini D, Polidori E, Potenza L, Guidi C, Stocchi V (1999) A new pair of primers designed for amplification of the ITS region in Tuber species. FEMS Microbiol Lett 173:239-245

Bickford D, Lohman DJ, Sodhi NS, Ng PKL,Meier R,WinkerK, Ingram KK, Das I (2007) Cryptic species as a window on diversity and conservation. Trends Ecol Evol 22:148-155. doi:10.1016/j.tree. 2006.11.004

Bonito GM, Gryganskyi AP, Trappe JM, Vilgalys R (2010) A global meta-analysis of Tuber ITS rDNA sequences: species diversity, host associations and long-distance dispersal. Mol Ecol 19:49945008. doi:10.1111/j.1365-294X.2010.04855.x

Bonito G, Smith ME, Nowak M, Healy RA, Guevara G, Cázares E, Kinoshita A, Nouhra ER, Domínguez LS, Tedersoo L, Murat C, Wang Y, Moreno BA, Pfister DH, Nara K, Zambonelli A, Trappe JM, Vilgalys R (2013) Historical biogeography and diversification of truffles in the Tuberaceae and their newly identified southern hemisphere sister lineage. PLoS ONE 8:e52765. doi:10.1371/ journal.pone.0052765

Bonuso E, Zambonelli A, Bergemann SE, lotti M, Garbelotto M (2009) Multilocus phylogenetic and coalescent analyses identify two cryptic species in the Italian bianchetto truffle, Tuber borchii Vittad. Conserv Genet 11:1453-1466. doi:10.1007/s10592-009-9972-3

Bordács S, Popescu F, Slade D, CsaikIUM, Lesur I, BorovicsA, Kézdy P, König AO, Gömöry D, Brewer S, Burg K, Petit RJ (2002) Chloroplast DNA variation of white oaks in northern Balkans and in the Carpathian Basin. Forest Ecol Manag 156:197-209

Bowden LC, Price EW, Carbone I (2008) SNAP Clade and Matrix, Version 2. Department of Plant Pathology, North Carolina State University, Raleigh, NC. Available at: http://www.cals.ncsu. edu/plantpath/faculty/carbone/home.html. Accessed on 25 Feb 2009

Bratek Z, Merényi Zs, Varga T (2013) Changes of hypogeous funga in the Carpathian-Pannonian region in the past centuries. Acta Mycol 48: 33-39. doi:10.5586/am.2013.005

Ceruti A, Fontana A, Nosenzo C (2003) Le specie europee del genere Tuber. Una revisione storica. Regione Piemonte Museo Regionale de Scienze Naturali, Monografie XXXVII., Torino 
Chen J, Guo SX, Liu PG (2011) Species recognition and cryptic species in the Tuber indicum complex. PloS ONE 6:e14625. doi:10.1371/ journal.pone.0014625

Chevalier G, Frochot H (1997) La truffe de Bourgogne. Pétrarque, Levallois-Perret, France. ISBN: 2911730-13-5

Chevalier G, Sourzat P (2012) Soils and techniques for cultivating Tuber melanosporum and Tuber aestivum in Europe. In: Zambonelli A, Bonito GM (eds) Edible Ectomycorrhizal Mushrooms. Springer, Berlin, pp 163-189

Clement M, Posada D, Crandall K (2000) TCS: a computer program to estimate gene genealogies. Mol Ecol 9(10):1657-1660

Douet JP, CastroviejoM, Mabru D, Chevalier G, Dupré C, Bergougnoux F, Ricard JM, Médina B (2004) Rapid molecular typing of Tuber melanosporum, T. brumale and T. indicum from tree seedlings and canned truffles. Anal Bioanal Chem 379:668-673. doi:10.1007/ s00216-004-2643-9

Drummond AJ, Suchard MA, Xie D, Rambaut A (2012) Bayesian phylogenetics with BEAUti and the BEAST 1.7. Mol Biol Evol 29(8):1969-1973. doi:10.1093/molbev/mss075

Farris JS, Kallersjo M, KlugemAG, Bult C (1995) Testing significance of incongruence. Cladistics 10:315-319. doi:10.1111/j.1096-0031. 1994.tb00181.x

Fu YX (1997) Statistical tests of neutrality of mutations against population growth, hitch- hiking, and background selection. Genetics 147: 915-925

Fu YX, LiWH (1993) Statistical tests of neutrality ofmutations. Genetics 133:693-709

Gandeboeuf D, Dupré C, Chevalier G (1994) Différenciation des truffes européennes par I' analyse des isoenzymes. Acta Bot Gallica 141: 455-463. doi:10.1080/12538078.1994.10515183

Gandeboeuf D, Dupré C, Chevalier G, Roeckel-Drevet P, Nicolas P (1997) Grouping and identification of Tuber species using RAPD markers. Can J Bot 75:36-45. doi:10.1139/b97-005

Gardes M, Bruns TD (1993) ITS primers with enhanced specificity for basidiomycetes-application to the identification of mycorrhizae and rusts. Mol Ecol 2:113-118

Geml J, Laursen GA, O' neill K, Nusbaum HC, Taylor DL (2006) Beringian origins and cryptic speciation events in the fly agaric (Amanita muscaria). Mol Ecol 15:225-239. doi:10.1111/j.1365-294X.2005.02799.x 
Ghikas DV, Kouvelis VN, Typas MA (2010) Phylogenetic and biogeographic implications inferred by mitochondrial intergenic region analyses and ITS1-5.8S-ITS2 of the entomopathogenic fungi Beauveria bassiana and B. brongniartii. BMC Microbiol 10:174

Giomaro G, Sisti D, Zambonelli A, Amicucci A, Cecchini M, Comandini O, Stocchi V (2002) Comparative study and molecular characterization of ectomycorrhizas in Tilia americana and Quercus pubescens with Tuber brumale. FEMS Microbiol Lett 216:9-14. doi:10.1111/j.15746968.2002.tb11407.x

Glez-Pena D, Gómez-Blanco D, Reboiro-JatoM, Fdez-Riverola F, Posada D (2010) ALTER: programoriented format conversion of DNA and protein alignments. Nucleic Acids Res. doi: $10.1093 / \mathrm{nar} / \mathrm{gkq} 321$

Grebenc T (2008) Research and cultivation of truffes in Slovenia- current status. In: Reynal B. (eds) La culture de la truffe dans le monde, acte du colloque, brive la gaillarde. Fevrier 2:183-191

Griffiths RC, Tavaré S (1994) Ancestral inference in population genetics. Stat Sci 9:307-319

Grivet D, Petit RJ (2003) Chloroplast DNA phylogeography of the hornbeam in Europe: evidence for a bottleneck at the outset of postglacial colonization. Conserv Geneti 4:47-56

Grubisha LC, Levsen N, Olson MS, Taylor DL (2012) Intercontinental divergence in the Populusassociated ectomycorrhizal fungus, Tricholoma populinum. New Phytol 194:548-560. doi:10.1111/j. 1469-8137.2012.04066.x

Guerin-Laguette A, Cummings N, Hesom-Williams N, Butler R,Wang Y (2013) Mycorrhiza analyses in New Zealand truffières reveal frequent but variable persistence of Tuber melanosporum in coexistence with other truffle species. Mycorrhiza 23:87-98. doi:10. 1007/s00572-012-0450-2

Guevara G, Bonito G, Cázares E, Rodríguez J, Vilgalys R, Trappe JM (2008) Tuber regimontanum, new species of truffle from Mexico. Rev Mex Micol 26:17-27

Hall IR, Brown G, Zambonelli A (2007) Taming the truffle: the history, lore, and science of the ultimate mushroom. Timber, Portland

Hatziskakis S, Papageorgiou AC, Gailing O, Finkeldey R (2009) High chloroplast haplotype diversity in Greek populations of beech (Fagus sylvatica L.). Plant Biol 11:425-433. doi:10.1111/j.14388677.2008.00111.x 
Hibbett DS (2001) Shiitake mushrooms and molecular clocks: historical biogeography of Lentinula. J Biogeogr 28:231-241. doi:10.1046/j. 1365-2699.2001.00528.x

Ho WH, Anderson S, Guerin-Laguette A, Hesom-Williams N, Wang Y, Braithwaite M, Hill CF, Alexander BJR (2008) Tuber brumale, a new truffle in New Zealand. ICPP2008, 9th International Congress of Plant Pathology, Torino (Italy), August 24-29

Hollós L (1911) Magyarország földalatti gombái, szarvasgombaféléi. K. M. Természettudományi Társulat, Budapest

Hudson RR, Boos DD, Kaplan NL (1992) A statistical test for detecting geographic subdivision. Mol Biol Evol 9:138-151

Huelsenbeck JP, Ronquist FR (2001) Mr. Bayes: Bayesian inference of phylogenetic trees. Biometrics $17: 754-755$

Jeandroz S, Murat C,Wang Y, Bonfante P, Le Tacon F (2008) Molecular phylogeny and historical biogeography of the genus Tuber, the "true truffles" . J Biogeogr 35:815-829. doi:10.1111/j.1365-2699.2007. 01851.x

Katoh K, Toh H (2008) Recent developments in the MAFFT multiple sequence alignment program. Brief Bioinform 9: 286-298

Kiss M, Csóka M, Győrfi J, Korány K (2011) Comparison of the fragrance constituents of Tuber aestivum and Tuber brumale gathered in Hungary. J Appl Bot Food Qual 84:102-110

Ławrynowicz M (1992) Distributional limits of truffles in the northern Europe. Micol Veg Mediterr $7(1): 31-38$

Li M, Liang J, Li Y, Feng B, Yang ZL, James TY, Xu J (2010) Genetic diversity of Dahongjun, the commercially important “Big Red Mushroom” from southern China. PloS ONE 5:e10684. doi:10. 1371/journal.pone.0010684

Librado P, Rozas J (2009) DnaSP v5: a software for comprehensive analysis of DNA polymorphism data. Bioinformatics 25: 1451-1452

Linzer RE, OtrosinaWJ, Gonthier P, Bruhn J, Laflamme G, Bussières G, Garbelotto M (2008) Inferences on the phylogeography of the fungal pathogen Heterobasidion annosum, including evidence of interspecific horizontal genetic transfer and of human-mediated, long-range dispersal. Mol Phylogenet Evol 46:844-862. doi:10. 1016/j.ympev.2007.12.010 
Lumbsch HT, Buchanan PK, May TW, Mueller GM (2008) Phylogeography and biogeography of fungi. Mycol Res 112:423- 424. doi:10.1016/j.mycres.2008.02.002

Magri D (2008) Patterns of post-glacial spread and the extent of glacial refugia of European beech (Fagus sylvatica). J Biogeogr 35:450- 463. doi:10.1111/j.1365-2699.2007.01803.x

Mamoun M, Olivier JM (1993) Competition between Tuber melanosporum and other ectomycorrhizal fungi under two irrigation regimes. Plant Soil 149:211-218. doi:10.1007/BF00016611

Marjanović Ž (2008) Truffles and possibilities for their cultivation in Serbia-current situation. In: Reynal B. (eds) la culture de la truffe dans le monde, acte du colloque, brive la gaillarde. Fevrier 2: $163-172$

Marjanović Ž, Grebenc T, Marković M, Glišić A, Milenković M (2010) Ecological specificities and molecular diversity of truffles (genus Tuber) originating from mid-west of the Balkan Peninsula. Sydowia 62(1):67-87

Markwordt J, Doshi R, Carbone I (2003) SNAP Clade and Matrix. Department of Plant Pathology, North Carolina State University, Raleigh, NC. Available at: http://www.cals.ncsu.edu/plantpath/ faculty/carbone/home.html. Accessed on 25 Feb 2009).

Martin F, Kohler A, Murat C, Balestrini R, Coutinho PM et al (2010) Périgord black truffle genome uncovers evolutionary origins and mechanisms of symbiosis. Nature 464:1033-1038. doi:10.1038/ nature08867

Moncalvo JM, Buchanan PK (2008) Molecular evidence for long distance dispersal across the Southern Hemisphere in the Ganoderma applanatum-australe species complex (Basidiomycota). Mycol Res 112:425-436. doi:10.1016/j.mycres.2007.12.001

Montecchi A, SarasiniM (2000) Funghi ipogei d' Europa. Associaazione Micologi ca Bresadola Fondacione centro Studi Micologici, Trento-Vicenza

Murat C, Díez J, Luis P, Delaruelle C, Dupré C, Chevalier G, Bonfante P, Martin F (2004) Polymorphism at the ribosomal DNA ITS and its relation to postglacial re-colonization routes of the Perigord truffle Tuber melanosporum. New Phytol 164:401-411. doi:10.1111/j. 14698137.2004.01189.x 
Nielsen R, Wakeley J (2001) Distinguishing migration from isolation: a Markov chain Monte Carlo approach. Genetics 158:885-896

Nilsson HR, Kristiansson E, Ryberg M, Hallenberg N, Larsson KH (2008) Intraspecific ITS variability in the kingdom fungi as expressed in the international sequence databases and its implications for molecular species identification. Evol Bioinformatics 4: 193-201

Nylander JAA (2004) MrModeltest v2. Program distributed by the author. Evolutionary Biology Centre, Uppsala University. http://www. abc.se/ nylander/mrmodeltest2/mrmodeltest2. (downloaded on 20 May 2012).

Olivier JM, Savignac JC, Sourzat P (2012) Truffe et trufficulture Éditions Falanc, Périgueux, 1996, 2002,2012

Palmé AE,Vendramin GG (2002) Chloroplast DNAvariation, postglacial recolonization and hybridization in hazel, Corylus avellana. Mol Ecol 11:1769-1779. doi:10.1046/j.1365294X.2002.01581.x

Petit RJ, Csaikl UM, Bordács S et al (2002a) Chloroplast DNAvariation in European white oaks: phylogeography and patterns of diversity based on data from over 2600 populations. Forest Ecol Manag 156: 5-26

Petit J, Brewer SR, Bordács S et al (2002b) Identification of refugia and post-glacial colonisation routes of European white oaks based on chloroplast DNA and fossil pollen evidence. Forest Ecol Manag 156:49-74

Petit RJ, Aguinagalde I, de Beaulieu JL et al (2003) Glacial refugia: hotspots but not melting pots of genetic diversity. Science 300:1563-1565

Pomarico M, Figliuolo G, Rana GL (2006) Tuber spp. biodiversity in one of the southernmost European distribution areas. Biodivers Conserv 16:3447-3461. doi:10.1007/s10531-006-90131

Posada D (2008) jModelTest: phylogenetic model averaging. Mol Biol Evol 25:1253-1256

Posada D (2011) Collapse: Describing Haplotypes from Sequence Alignments. Version 1.2. Website last modified on May 28, 2011. http://darwin.uvigo.es/software/collapse.html. Accessed 28 Jun 2012 
Price EW, Carbone I (2005) SNAP: workbench management tool for evolutionary population genetic analysis. Bioinformatics 21:402-404

Rambaut A (2009) FigTree v1.3.1: Tree Figure Drawing Tool. Available from http://tree.bio.ed.ac.uk/software/figtree/.(downloaded on 09 Feb 2012)

Rambaut A, Drummond AJ (2009) Tracer. Version 1.5. Available at http://beast.bio.ed.ac.uk.

Riousset L, Riousset G, Chevalier G, BardetMC(2001) Truffes d’ Europe et de Chine. INRA, Paris

Shannon P, Markiel A, Ozier O, Baliga NS, Wang JT, Ramage D, Amin N, Schwikowski B, Ideker T (2003) Cytoscape: a software environment for integrated models of biomolecular interaction networks. Genome Res 13(11):2498-2504

Sheedy EM, Van de Wouw AP, Howlett BJ, May TW (2013) Multigene sequence data reveal morphologically cryptic phylogenetic species within the genus Laccaria in southern Australia. Mycologia 105: 547-563. doi:10.3852/12-266

Sica M, Gaudio L, Aceto S (2007) Genetic structure of Tuber mesentericum Vitt. based on polymorphisms at the ribosomal DNA ITS. Mycorrhiza 17:405-414. doi:10.1007/s00572-0070115-8

Slatkin M, Hudson RR (1991) Pairwise comparisons of mitochondrial DNA sequences in stable and exponentially growing populations. Genetics 129:555-562

Sourzat P (2011) Black truffle cultivation and competing fungi. In: Savoie JM, Foulongne-Oriol M, Largeteau M, Barroso G, (eds) Proceedings of the 7th International Conference on Mushroom Biology and Mushroom Products. Arcachon, France, 4-7. October. 2011. pp 516-528.

Stielow B, Bratek Z, Orczán AKI, Rudnóy S, Hensel G, Hoffmann P, Klenk HP, Göker M (2011) Species delimitation in taxonomically difficult fungi: the case of Hymenogaster. PloS ONE 6:e15614. doi: 10.1371/journal.pone.0015614 Swofford DL (2003) PAUP*. Phylogenetic Analysis Using Parsimony (*and Other Methods). Version 4. Sinauer Associates, Sunderland, Massachusetts

Taberlet P, Fumagalli L,Wust-Saucy AG, Cosson JF (1998) Comparative phylogeography and postglacial colonization routes in Europe. Mol Ecol 7:453-464

Tajima $F$ (1989) Statistical method for testing the neutral mutation hypothesis by DNA polymorphism. Genetics 123:585-595 
Tamura K, Peterson D, Peterson N, Stecher G, Nei M, Kumar S (2011) MEGA 5: molecular evolutionary genetics analysis using maximum likelihood, evolutionary distance, and maximum parsimony methods. Mol Biol Evol 28:2731-2739

Taylor JW, Jacobson DJ, Kroken S, Kasuga T, Geiser DM, Hibbett DS, Fisher MC (2000) Phylogenetic species recognition and species concepts in fungi. Fungal Genet Biol 31:21-32. doi:10.1006/fgbi. 2000.1228

Urban A, Stielow B, Orczán AKI, Varga T, Tamaskó G, Bratek Z (2013) High phylogenetic diversity in the Tuber excavatum group. First International Congress of Trufficulture. p 73. Teruel, Spain. 58. 03.2013

Van de Putte K, Nuytinck J, Stubbe D, Le HT, Verbeken A (2010) Lactarius volemus sensu lato (Russulales) from northern Thailand: morphological and phylogenetic species concepts explored. Fungal Divers 45:99-130. doi:10.1007/s13225-010-0070-0

Vilgalys R, HesterM(1990) Rapid genetic identification and mapping of enzymatically amplified ribosomalDNAfromseveral Cryptococcus species. J Bacteriol 172:4238-4246

Wang Y, Tan ZM, Zhang DC, Murat C, Jeandroz S, Le Tacon F (2006) Phylogenetic relationships between Tuber pseudoexcavatum, a Chinese truffle, and other Tuber species based on parsimony and distance analysis of four different gene sequences. FEMSMicrobiol Lett 259:269-281. doi:10.1111/j.1574-6968.2006.00283.x

Watterson GA (1975) On the number of segregating sites in genetic models without recombination. Theor Popul Biol 10:256-276

White TJ, Bruns T, Lee S, Taylor JW (1990) Amplification and direct sequencing of fungal ribosomal RNA genes for phylogenetics. In: Innis MA, Gelfand DH, Sninsky JJ, White TJ (eds) PCR protocols: a guide to methods and applications.Academic, New York, pp 315-322 
Fig. 1 Bayesian phylogenetic tree of Melanosporum major clade based on LSU. Bayesian posterior probabilities (PP) and maximum parsimony (MP) bootstrap values divided by / are displayed above branches, only values where PP $>0.95$ and MP bootstrap support $>70 \%$ are shown. Numbers of OTUs on collapsed branches parenthetically follow species names. See accession numbers in Online Resource 3.Clades A and Bof Tuber brumale as well as specimens belonging to haplogroups I or II are marked. Specimens of Tuber brumale aggr. are shown with their identifiers listed in Online Resource 1

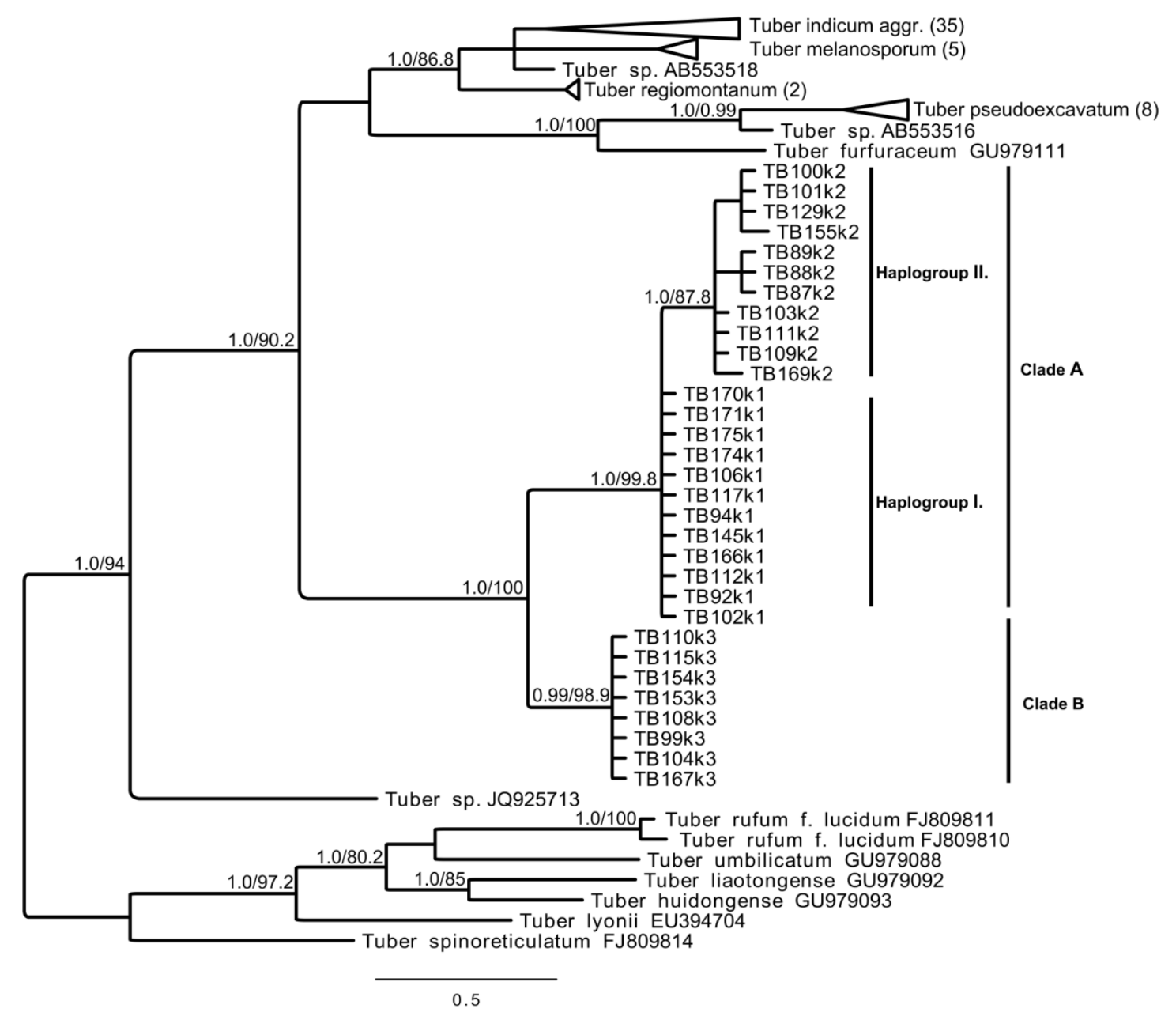


Fig. 2 Bayesian phylogenetic tree of T. brumale aggr. based on PKC. Bayesian posterior probabilities (PP) and maximum parsimony (MP) bootstrap values divided by / are shown above branches. Only values where PP $>0.95$ andMP bootstrap support $>70 \%$ are shown. Specimens of Tuber brumale aggr. are shown with their identifiers listed in Online Resource 1

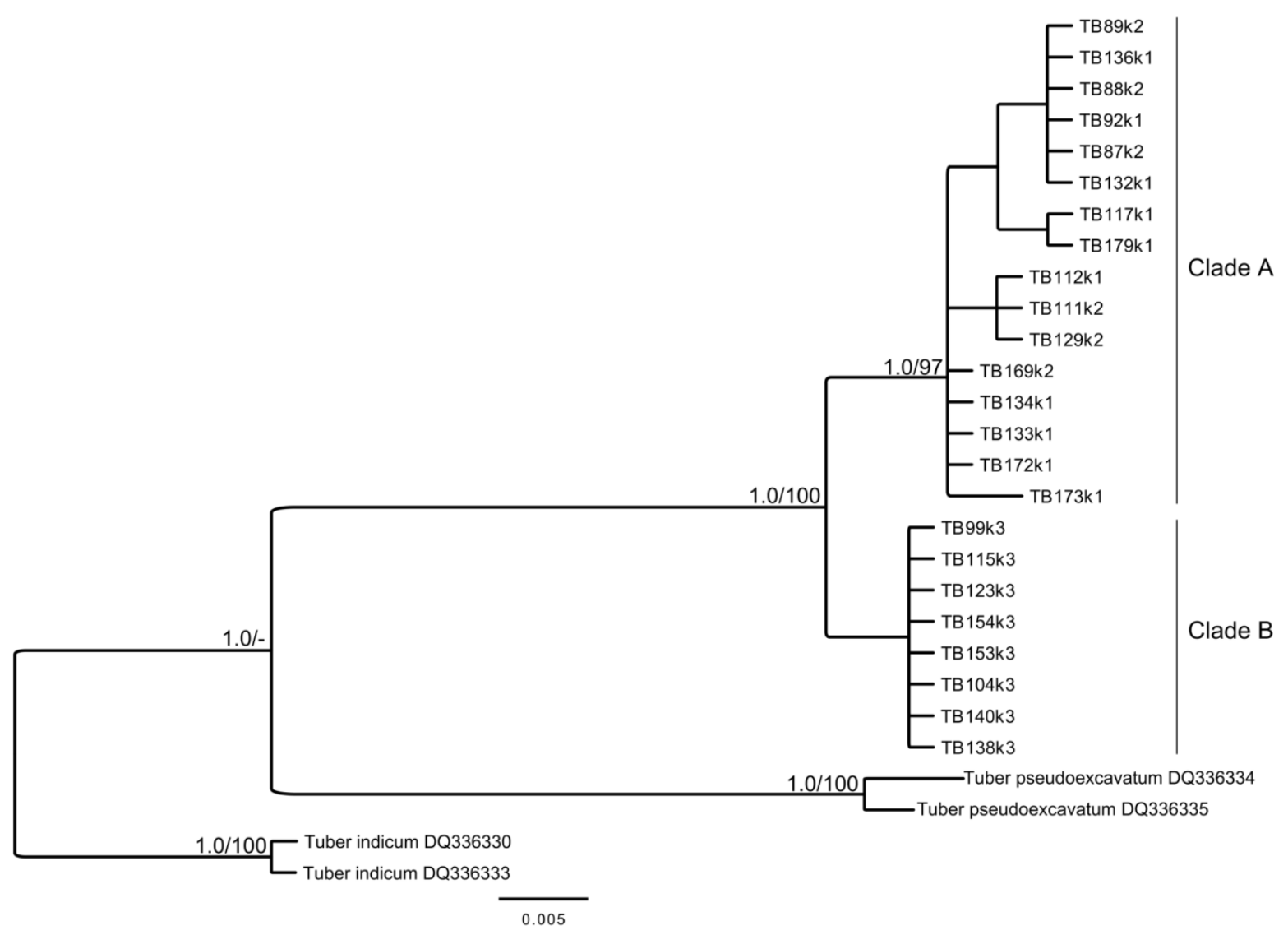


Fig. 3 Haplotype network and distribution of Tuber brumale aggr. in Europe based on the 17 haplotypes separated by the collapse program. Haplotypes designated with letters only were found to be identical regardless of coalescent analyses method, except that haplotypes A and B were merged by the collapse program, while haplotypes signified with both letters and numbers were recognised only by the collapse program. The sizes of circles are proportional to the number of samples. Specimens not depicted on the map are TB20k1 (New Zealand), TB169k2 (Turkey), TB46k2 (Iran) and TB47k2 (Iran). Maps were generated applying the QuantumGIS mapping software (http://qgis.org) using the world map of APRS ${ }^{\text {TM }}$ (http://aprsworld.net/gisdata/world/)

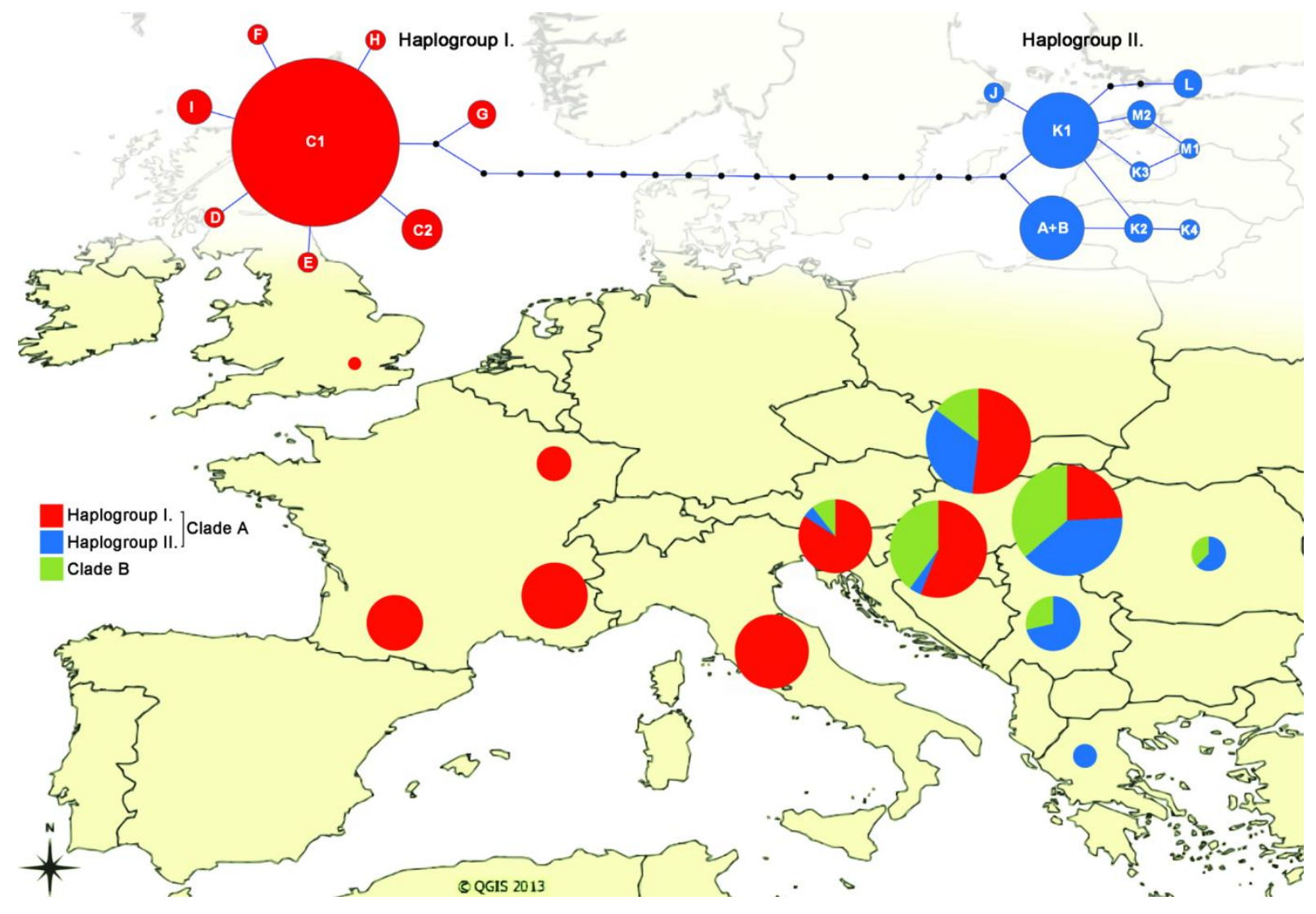


Fig. 4 Coalescent-based genealogy of T. brumale with the highest root probability (likelihood scores: $\mathrm{L}=1.9518 \times 10-17, \mathrm{SD}=1.1488 \times 10-17)$ showing the distribution of mutations for the ITS region. The inferred genealogy is based on 2,000,000 simulations of the coalescent with aWatterson's (1975) estimate of $\theta=1.9$. The time scale is in coalescent units of $2 N$, where $N$ is the population size.Mutations and bifurcations are time ordered from the top (past) to the bottom (present). Mutation designations correspond to the site numbers inTable 3.The numbers below the tree designate the distinct haplotypes and their observed frequencies in total and in the different geographical regions, where $0=$ Eastern, $1=$ Western Europe

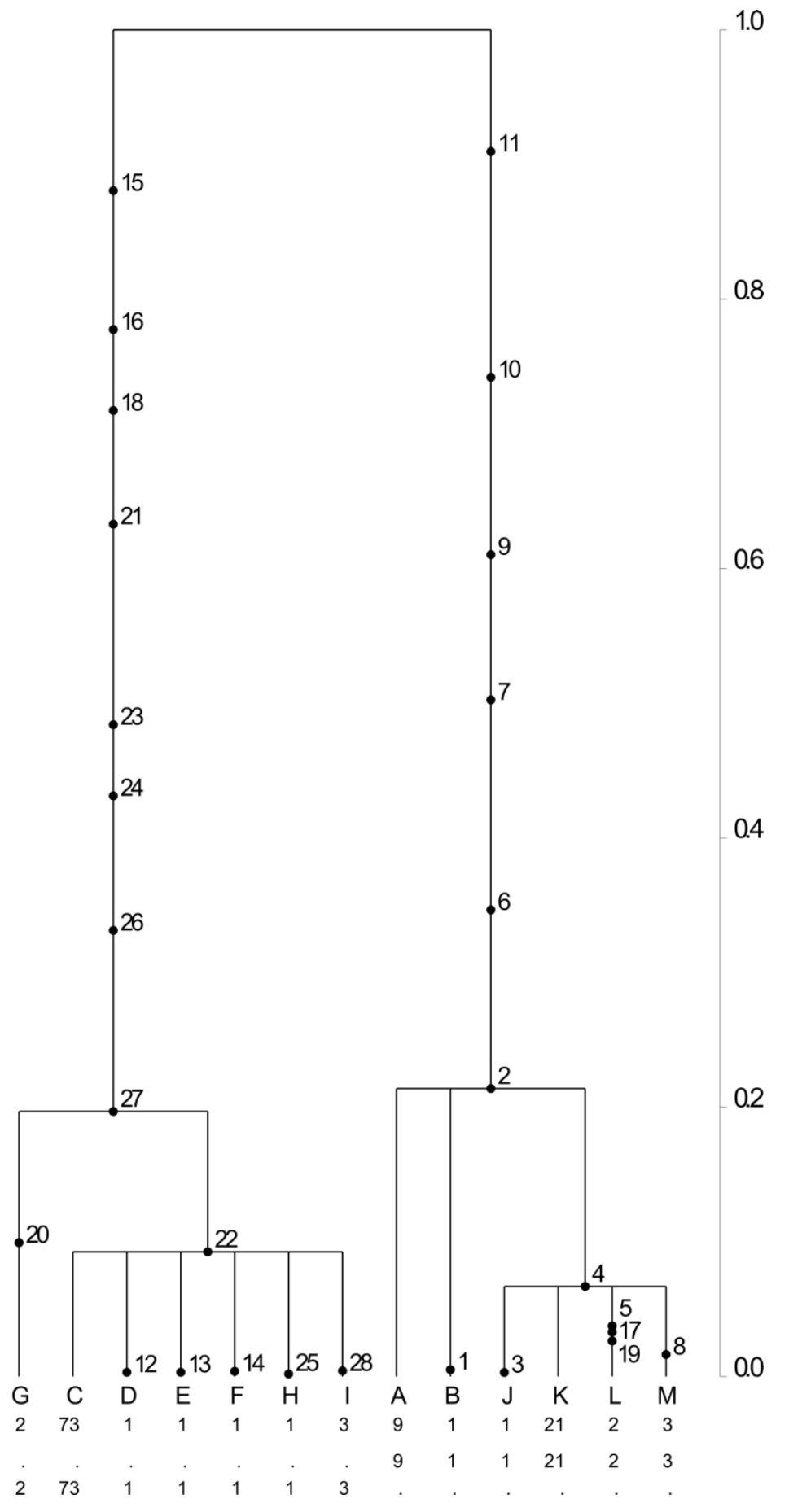


Table 1 Data for phylogenetic trees calculated with the maximum parsimony method Region

\begin{tabular}{|c|c|c|c|c|c|c|c|c|c|c|}
\hline $\begin{array}{l}\stackrel{\tilde{0}}{\infty 0} \\
\stackrel{0}{\simeq}\end{array}$ & 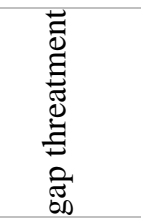 & 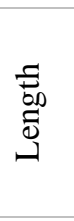 & U & $\ddot{q}$ & $\approx$ & $\begin{array}{l}\text { 亏े } \\
\text { b् } \\
\overline{0}\end{array}$ & 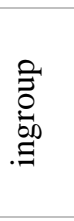 & 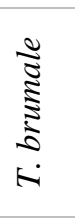 & $\frac{n}{2}$ & 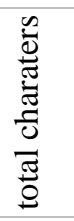 \\
\hline \multirow{2}{*}{ ITS } & missing & 215 & 0.926 & 0.992 & 0.918 & 4 & 136 & 136 & 176 & 762 \\
\hline & 5th char. & 722 & 0.910 & 0.981 & 0.892 & 4 & 136 & 136 & 507 & 762 \\
\hline \multirow{2}{*}{ LSU } & missing & 301 & 0.631 & 0.942 & 0.595 & 7 & 85 & 31 & 121 & 523 \\
\hline & 5th char. & 310 & 0.639 & 0.942 & 0.601 & 7 & 85 & 31 & 126 & 523 \\
\hline \multirow{2}{*}{ PKC } & missing & 77 & 0.987 & 0.994 & 0.981 & 4 & 24 & 24 & 65 & 735 \\
\hline & 5th char. & 86 & 0.988 & 0.994 & 0.983 & 4 & 24 & 24 & 73 & 735 \\
\hline
\end{tabular}

Further features displayed are the length of trees, the number of total characters, the number of parsimony informative sites (PIS), the number of outgroups and ingroups and the number of samples belonging to Tuber brumale aggr. among ingroups

$\mathrm{Cl}$ consistency index, $\mathrm{RI}$ retention index, $\mathrm{RC}$ rescaled consistency index 
Table $2 \mathrm{P}$ distance matrix based on ITS sequences Clade/haplogroup

\begin{tabular}{ccccc}
\hline clade/haplogroup & I. & II. & B & A \\
\hline Haplogroup I. & $0.032 \%$ & $2.024 \%$ & $9.258 \%$ & \\
& $0.073 \%$ & $0.094 \%$ & $0.085 \%$ & \\
Haplogroup II. & & $0.201 \%$ & $9.450 \%$ & \\
& & $0.166 \%$ & $0.254 \%$ & \\
Clade B & & & $0.070 \%$ & $9.317 \%$ \\
& & & $0.067 \%$ & $0.181 \%$ \\
Clade A & & & & $0.909 \%$ \\
& & & & $0.979 \%$
\end{tabular}

The upper values in cells are averages and the lower values are standard deviations 
Table 3 Polymorphic sites in the ITS haplotypes of Tuber brumale collapsed after recoding indels and removing infinite-sites violations from the original ITS dataset for the subsequent coalescent analyses. Haplotype designations, position, site number, and designation of the givenmutation are as shown in Fig. 4. Position refers to that in the original alignment, site type refers either transition $(t)$, transversion (v), deletion (-) change with regard to the consensus sequence

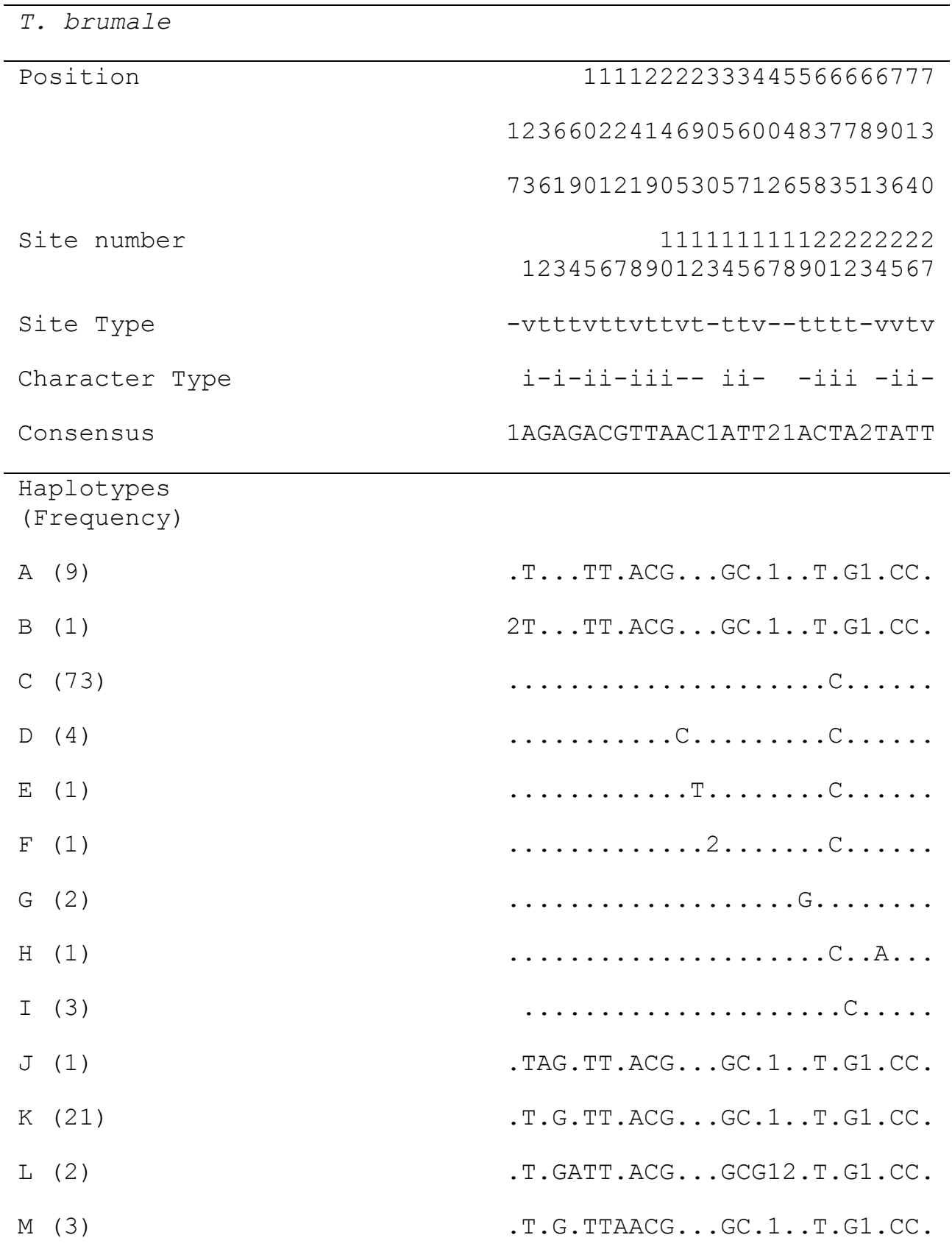

